\title{
PENINGKATAN PARTISIPASI DAN KOMPETENSI MATEMATIS MELALUI BLENDED LEARNING
}

\author{
Edi Prayitno, Badjuri, Kristi Liani Purwati \\ edip@ecampus.ut.ac.id; badjuri@ecampus.ut.ac.id; liani.lia81@gmail.com
}

\begin{abstract}
Abstrak
Fenomena maraknya permainan Pokemon Go di antara para siswa dan mahasiswa mencerminkan kemudahan dan keterampilan warga memperoleh akses informasi di dunia maya. Fenomena ini juga mencerminkan banyaknya waktu luang yang dimiliki para siswa di rumah. Ketersediaan waktu luang dan kemudahan akses informasi di dunia maya dapat kita manfaatkan untuk menambah intensitas partisipasi belajar di luar pembelajaran.

Saat kita memaparkan suatu materi di kelas, tidak tertutup kemungkinan terdapat beberapa siswa yang sudah menguasai materi yang kita sajikan.Mereka telah mempelajarinya berdasarkan suatu sumber yang diperoleh secara online. Akibatnya paparan materi saat pembelajaran di kelas tidak sepenuhnya diikuti oleh para siswa. Selain merupakan suatu 'kerugian waktu' dari proses pembelajaran yang telah direncanakan oleh guru, kejadian ini juga membuka kesempatan terjadinya informasi yang saling bertentangan antara materi yang disajikan dengan materi yang ada telah dipelajari siswa dari dunia maya. Terbukanya akses berbagai sumber materi secara online seharusnya sudah kita sadari. Sejak awal seharusnya kita sudah memperhitungkan keberadaan materi online dan memfasilitasi siswa untuk mengaksesnya secara terarah melalui rancangan pembelajaran berbantuan media online. Rancangan pembelajaran berbantuan media online ini dapat meningkatkan partisipasi siswa di luar jam pembelajaran tatap muka untuk memaksimalkan prestasi belajar.

Blended Learning merupakan salah satu bentuk pendidikan yang memanfaatkan $e$ Learningdalam proses pelaksanaannya. Kombinasi antara kegiatan pembelajaran tatap muka dan pembelajaran onlinememungkinkan siswa memperoleh tambahan waktu mengikuti proses pembelajaran dan kesempatan untuk memperluas cakrawala materi melalui sumber lain. Partisipasi yang biasa diperoleh siswa dalam pembelajaran tatap muka dibatasi waktunya setelah paparan materi.
\end{abstract}

Kata kunci : peningkatan partisipasi, kompetensi matematika, blended learning 


\section{PENDAHULUAN}

Fenomena maraknya permainan Pokemon Go di antara para siswa dan mahasiswa mencerminkan kemudahan dan keterampilan warga memperoleh akses informasi di dunia maya. Fenomena ini juga mencerminkan banyaknya waktu luang yang dimiliki para siswa di rumah. Ketersediaan waktu luang dan kemudahan akses informasi di dunia maya dapat kita manfaatkan untuk menambah intensitas partisipasi belajar di luar pembelajaran.

Saat kita memaparkan suatu materi di kelas, tidak tertutup kemungkinan terdapat beberapa siswayang sudah menguasai materi yang kita sajikan.Mereka telah mempelajarinya berdasarkan suatu sumber yang diperoleh secara online. Akibatnya paparan materi saat pembelajaran di kelas tidak sepenuhnya diikuti oleh para siswa. Selain merupakan suatu 'kerugian waktu' dari proses pembelajaran yang telah direncanakan oleh guru, kejadian ini juga membuka kesempatan terjadinya informasi yang saling bertentangan antara materi yang disajikan dengan materi yang ada telah dipelajari siswa dari dunia maya. Terbukanya akses berbagai sumber materi secara online seharusnya sudah kita sadari. Sejak awal seharusnya kita sudah memperhitungkan keberadaan materi online dan memfasilitasi siswa untuk mengaksesnya secara terarah melalui rancangan pembelajaran berbantuan media online. Rancangan pembelajaran berbantuan media online ini dapat meningkatkan partisipasi siswa di luar jam pembelajaran tatap muka untuk memaksimalkan prestasi belajar.

Hasil penelitian Eva Van de Gaer dkk pada tahun 2008 menunjukkan bahwa ada hubungan yang saling mempengaruhi antara partisipasi dan prestasi belajar matematika khususnya untuk siswa kelas 10 dan 12. Prestasi siswa pria lebih baik dari wanita terkait dengan partisipasi mereka yang lebih tinggi selama pembelajaran matematika (Gaer, 2008). Penelitian Nurmawati dkk pada tahun 2015 memperlihatkan bahwa pemanfaatan e-modul dalam tutorial Pendidikan Matematika II bagi para mahasiswa PGSD secara efektif meningkatkan kemampuan mahasiswa melalui penambahan intensitas partisipasi di luar tutorial tatap muka (Nurmawati, 2015). Namun untuk memanfaatkan informasi di dunia maya bagi peningkatan partisipasi dan kompetensi belajar perlu pemahaman yang mendalam tentang langkah mengintegrasikan pembelajaran online dengan pembelajaran tatap muka. 


\section{PEMBAHASAN}

\section{Kompetensi, Kepercayaan diri dan Partisipasi Matematis}

Dalam model fluiditas interaksi sosial, partisipasi, posisi, peran dan pelaksanaan dimaknai dengan suatu tingkatan yang berbeda. Peran (misalnya peran sebagai guru dan siswa) dimaknai sebagai suatu status dalam suatu lembaga. Peran merupakan suatu bentuk kategorisasi yang bertahan lama. Posisi (misalnya sebagai kepala sekolah atau tenaga operasional atau tenaga ahli) adalah status sosial yang dibangun melalui interaksi dari kelompok sosial yang lebih kecil dari sebuah institusi. Posisi terkait dengan keanggotaan dalam suatu sistem operasi dan kurang kuat dalam keanggotaannya. Partisipasi adalah mekanisme sosial yang dipengaruhi oleh posisi dan peran. Pola partisipasi mencerminkan keteraturan praktik dalam sistem sosial tergantung pada posisi dan peran yang dimainkan (Clarke, 2004). Dalam pembelajaran, partisipasi siswaditentukan oleh pola interaksi yang dirancang guru.

Pola interaksi dalam pembelajaran matematika yang sering muncul adalah guru menyajikan materi yang dilanjutkan dengan penyajian permasalahan atau pertanyaan. Siswa merespon dengan menunjukkan kesediaan untuk menjawab, guru menunjuk siswa yang merespon tersebut kemudian menilai jawabannya benar atau salah. Bila salah satu siswa dapat memberikan jawaban yang benar, guru sering salah menyimpulkan bahwa kompetensi tersebut telah dikuasai seluruh siswa meskipun beberapa jawaban siswa sebelumnya dinilai tidak tepat. Pola interaksi ini diulang beberapa kali sampai alokasi waktu tanya jawab selesai. Pola interaksi ini memiliki kelemahan, yaitu: 1) Guru mengalami kesulitan dalam mengingat siswa yang telah berpartisipasi dan yang tidak berpartisipasi serta kualitas partisipasinya; 2) Guru tidak bisa menjamin ketuntasan penguasaan kompetensi setiap siswa (The Reflective Educator, 2015).

Kompetensi dimaknai sekumpulan keterampilan atau kemampuan yang ditunjukkan seseorang dalam suatu kegiatan. Suatu kompetensi dibentuk melalui suatu proses tertentu, oleh karena itu suatu kompetensi akan terlihat berbeda antara satu proses kegiatan dengan kegiatan yang lainnya. Pengembangan suatu kompetensi dalam suatu pembelajaran menuntut fokus analisis perorangan selama proses pembelajaran. Analisis perorangan selama pembelajaran hampir tidak mungkin dilakukan oleh guru sendirian.Sebagai konsekuensianya, guru dapatmenilai kompetensi siswa tidak lagi dari tingkat kemampuannya tetapi dilihat dari interaksinya saat berpartisipasi dalam pembelajaran (Gresalfi dkk, 2009).

Matematika bukanlah sebuah mata pelajaran yang bagi sebagian besar siswa merupakan hal yang biasa dibicarakan dan dilakukan setiap hari. Belajar matematika oleh siswa dimaknai 
menyelesaikan tugas dan menyerahkan ke guru untuk dinilai. Kegiatan mendiskusikan suatu masalah, mendengarkan pendapat yang berbeda dan membangun pendapat bersama tidak dianggap sebagai kegiatan matematis (Civil \& Planas, 2004). Dalam setiap kegiatan atau permainan seseorang dituntut untuk dapat menentukan aturan pelaksanaannya, Saat melakukan kegiatan tersebut tidak jarang melibatkan kegiatan matematis. Bila seseorang dapat menunjukkan bagaimana ilmu matematika dimanfaatkan dalam kegiatan tersebut, maka mereka dapat dikatakan telah melakukan kegiatan matematika, telah berpartipasi matematis.

Menentukan tingkat dan jenis partisipasi matematis yang terkait dengan peningkatan suatu kompetensi matematika bukanlah suatu pekerjaan yang sulit. Pembelajaran matematika tatap muka di kelas merupakan hasil interaksi siswa dengan guru, dengan materi kurikulum, dengan sarana dan prasarana yang berupa perangkat keras, perangkat lunak dan lingkungan fisik. Interaksi tersebut dilakukan secara aktif dalam mengembangkan suatu kompetensi. Apapun bentuk interaksi aktif siswa dengan komponen pembelajaran yang lain dapat dikategorikan sebagai partisipasi matematis.

Namun demikian, guru sering kali mengabaikan peran partisipasi dalam pembelajaran. Dengan pertimbangan menghemat waktu dalam memaparkan materi pelajaran, tidak jarang para guru membatasi partisipasi siswa hanya saat latihan penyelesaian soal dan evaluasi. Penyampaian pertanyaan kepada siswa juga didasarkan pada penggunaan waktu secara efisien. Pertanyaan diberikan secara klasikal dalam bentuk paket latihan yan ditulis dalam lembar kerja atau di papan tulis. Komunikasi perorangan saat penyampaian pertanyaan hampir ditiadakan. Penggunaan waktu yang serba dibatasi inilah yang menyebabkan terbatasnya partisipasi siswa dalam proses belajar. Keterbatasan partisipasi siswa dalam pembelajaran salah satunya dapat membatasi akses siswa berlatih dan memperoleh pengalaman menghadapi permasalahan matematika. Keterbatasan pengalaman membuat kurang tumbuhnya kepercayaan diri siswa saat menghadapi permasalahan matematika.

Kepercayaan diri membawa dampak terhadap proses belajar dan prestasi matematika pada aspek kognitif, motivasi, afektif dan pada proses pengambilan keputusan (OECD, 2013). Dampak-dampak tersebut menentukan seberapa besar mereka memotivasi diri dan tangguh dalam menghadapi kesulitan serta mempengaruhi emosi siswa (Bandura dalam OECD, 2013) yang pada akhirnya mempengaruhi perilaku dan partisipasi siswa dalam proses pembelajaran. Berikut ini adalah gambar dampak berantai akibat kurangnya kepercayaan diri terhadap perilaku matematis: 


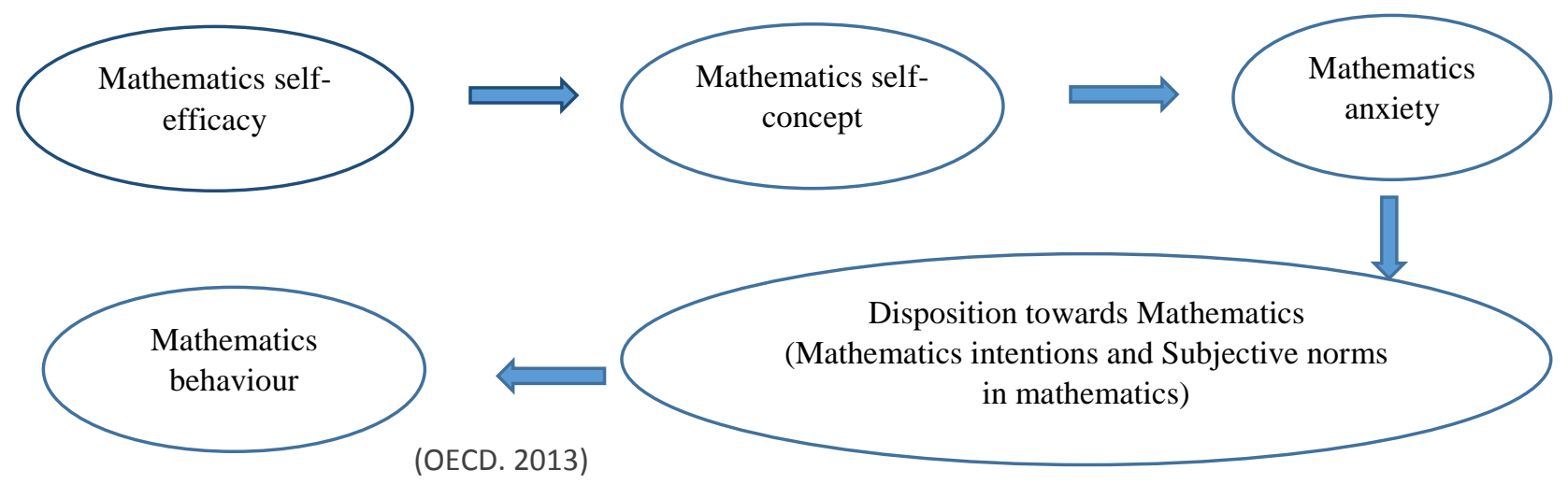

Gambar 1. Mathematics Self-Beliefs, Dispositions and Participation in Mathematics-related Activities

Rasa percaya diri terhadap kemampuan menyelesaikan masalah matematika (Mathematics self-efficacy) ditentukan berdasarkan kepercayaan diri dalam menyelesaikan berbagai permasalahan matematika, baik matematika murni maupun matematika terapan. Kepercayaan diri selanjutnya mempengaruhi konsep matematis yang dimiliki seseorang (Mathematics self concept). Indeks konsep matematis ditentukan berdasarkan jawaban siswa dalam uji kompetensi menyelesaikan soal matematika. Tinggi rendahnya konsep matematis yang dimiliki seseorang berpengaruh langsung pada kecemasan matematis (Mathematics anxiety). Indeks kecemasan matematis ditentukan berdasarkan jawaban siswa tentang perasaannya terkait dengan stress dan ketidakberdayaan ketika berhadapan dengan soal-soal matematika. Tingkat kecemasan seorang siswa manakala menghadapi soal soal matematika mempengaruhi sikapnya terhadap segala sesuatu yang berhubungan dengan matematika. Sikap senang atau tidak senang terhadap matematika diujudkan dalam bentuk perilaku dan partisipasinya dalam kegiatan yang terkait dengan masalah matematika.

Banyak cara untuk meningkatkan partisipasi siswa dalam pembelajaran matematika. Guru atau tutor bisa memunculkan berbagai kegiatan yang dapat menambah partisipasi siswa selama proses pembelajaran di kelas. Beberapa contoh kegiatan yang dapat meningkatkan partisipasi siswa selama pembelajaran, antara lain:

1. Memberi kesempatan mendiskusikan permasalahan dengan teman sebangku. Guru berkeliling dan menyimak para siswa yang berdikusi. Setelah memastikan bahwa para siswa telah aktif berpartisipasi dalam berdiskusi, guru meminta beberapa siswa menyampaikan hasil diskusinya. Kegiatan berdiskusi berpasangan dapat memberi kesempatan pada semua siswa untuk menyampaikan gagasannya kepada sekurang- 
kurangnya satu teman dan meningkatkan jumlah waktu partisipasi dalam memproses dan memikirkan permasalahan (OECD, 2013; USciences, 2016).

2. Menambah waktu bagi siswa untuk memikirkan jawaban sebelum pertanyaan berikutnya diberikan. Penambahan waktu berpikir berarti menambah waktu siswa berpartisipasi aktif menyelesaikan masalah (OECD, 2013; USciences, 2016).

3. Mengubah pertanyaan yang ditujukan kepada perseorangan atau suatu kelompok diganti ditujukan untuk seluruh kelas. Pengajuan pertanyaan secara terbuka ini memberi kesempatan kepada seluruh kelas untuk berpartisipasi memikirkan jawaban atas pertanyaan yang diajukan (OECD, 2013; USciences, 2016).

4. Memberi kesempatan yang lebih besar kepada siswa untuk mengontrol proses pembelajaran. Partisipasi mereka dimulai dari ikut merencanakan tujuan, menentukan jenis kegiatan pembalajaran, menentukan cara mencapainya dan melaksanakan pembelajaran. Siswa merasa memiliki, memahami arah yang akan dicapai dan mengetahui bagaimana cara mencapainya sehingga dapat tercipta proses belajar yang lebih baik (OECD, 2013; USciences, 2016).

5. Menugaskan para siswa menyusun dan saling menjawab pertayaan. Partisipasi siswa tidak hanya memahami wacana untuk menyelesaikan pertanyaan, namun memahami wacana untuk menyusun pertanyaan dan menjawab pertanyaan siswa yang lain (OECD, 2013).

6. Melibatkan para siswa dalam kegiatan pemecahan masalah. Para siswa dilibatkan mulai dari penemuan masalah, kerja interaktif dalam kelompok dalam menemukan penyelesaian, latihan perorangan, pelaporan temuan, masukan dari siswa lain dan penarikan simpulan (OECD, 2013; USciences, 2016).

7. Menggunakan sarana non verbal seperti mengatur tempat duduk, duduk dekat siswa, kontak mata perseorangan, berkeliling kelas atau duduk berpindah-pindah (USciences, 2016).

8. Melibatkan sarana online dalam pembelajaran (USciences, 2016).

Seiring dengan kemajuan teknologi informasi dan telekomunikasi saat ini, kemungkinan peningkatan partisipasi siswa dalam pembelajaran yang terbesar dapat diperoleh dengan melibatkan sarana online, atau yang disebut e-Learning.Kemungkinan ini terbentuk karena e-Learning menyimpan data yang tidak terhingga yang oleh Pappas (2014) disebut sebagai Big Data. 


\section{Pembelajaran Online (E-Learning)}

Istilah Big Data dalam industri e-Learning adalah data yang diciptakan oleh para siswa saat mereka berpartisipasi dalam pembelajaran online atau data dalam modul latihannya. Istilah ini tidak hanya mengacu pada volume data semata, tetapi mengacu pada jumlah individu yang berkecimpung di dalamnya (Pappas, 2014). Semakin lama pengguna e-Learning semakin banyak sehingga data yang tercipta semakin tidak dapat ditentukan jumlahnya.

Data yang melimpah dan dapat diakses oleh semua orang memunculkan beberapa kelebihan dari e-Learning, antara lain:

1. Memungkinkan para profesional e-Learning memahami cara siswa mencerna informasi dan memilih bentuk pembelajaran yang paling sesuai.

2. Memungkinkan para profesional e-Learning menentukan sumber materi yang mereka butuhkan untuk pembelajaran dan menyusun modul.

3. Memberikan bahan analisis tentang materi modul e-Learning yang paling banyak dikunjungi dan disebarkan ke siswa yang lain.

4. Data dapat diterima dalam waktu yang sangat singkat sehingga dapat segera diterapkan.

5. Dengan pola-pola pembelajaran yang ditawarkan, para professional dapat memperkirakan tingkat kesulitan siswa. Kemudian mereka mengembangkan pembelajaran yang memberi kesempatan kepada siswa untuk berhasil. (Pappas, 2014)

Ketersediaan data yang melimpah tidak sertamerta menjamin pemanfaatan yang efektif dalam pembelajaran. Dibutuhkan suatu teori sebagai batu pijakan untuk mengelola data yang melimpah tersebut. Sebuah teori dapat dijelaskan sebagai seperangkat hipotesis yang diterapkan pada semua kondisi suatu fenomena, membantu dalam penentuan keputusan dan menjadi filosofi suatu kegiatan. (Nichols, 2003).Secara operasional pemanfaatan data web untuk keperluan pembelajaran harus berdasar pada hipotesis tentang e-Learning. Ada sepuluh hipotesis yang menjadi prinsip dasar e-Learning, yaitu:

1. e-Learning adalah suatu sarana implementasi pendidikan yang dapat diterapkan dalam berbagai model pendidikan (baik tatap muka maupun jarak jauh) dan dalam berbagai filosofi pendidikan seperti behaviourism dan construktivis. Prinsip ini menegaskan bahwa e-Learning merupakan suatu sarana pendidikan bukan suatu model pendidikan.

2. e-Learning menciptakan suatu bentuk pendidikan yang unik yang cocok dengan paradigma pendidikan tatap muka dan pendidikan jarak jauh. e-Learning memungkinkan 
terciptanya bentuk pendidikan baru yang mengkombinasikan antara pendidikan tatap muka dan pendidikan jarak jauh dalam berbagai cara.

3. Pemilihan perangkat e-Learning lebih mencerminkan bukannya menentukan pedogagogik suatu pembelajaran; lebih mengutamakan cara penggunaan teknologi dari pada menentukan jenis teknologi yang digunakan. Keberhasilan e-Learning lebih ditentukan oleh pengguna teknologi dan cara mengimplementasikan teknologi tersebut bukan pada jenis teknologi yang digunakan.

4. e-Learningakan mengalami kemajuan terutama melalui penerapan inovasi pedagogi yang tepat, bukan melalui pemilihan teknologi. Hanya pendidik yang inovatif yang mampu memaksimalkan e-Learning.

5. e-Learning dapat digunakan dalam dua cara utama, yaitu sebagai sarana untuk menyajikan materi pelajaran dan sebagai fasilitator proses pembelajaran. Aplikasi $e$ Learning antara lain digunakan untuk menyimpan dan distribusi materi, komunikasi, interaktif, multimedia dan melacak akses.

6. Sarana e-Learning dapat berfungsi secara maksimal bila dipilih secara cermat dan secara optimal diintegrasikan dalam model pembelajaran.

7. Teknik dan sarana e-Learning digunakan setelah melalui pertimbangan yang cermat tentang untung rugi pembelajaran tatap muka dan pembelajaran online.

8. Pelaksanaan e-Learningyang efektif selalu mempertimbangkan bahwa para pengguna dapat memperoleh kesempatan belajar yang maksimal. Pemahaman perilaku pengguna merupakan langkah yang utama dalam pelaksanaan e-Learning dan perlu secara cermat dipersiapkan.

9. Seperti pendidikan tatap muka, e-Learning juga focus pada tercapainya tujuan pendidikan, yaitu mengembangkan peserta didik. Tanpa keraguan sarana e-Learning digunakan untuk mendorong para siswa mengeksplorasi materi pelajaran sesuai kemampuan mereka sendiri.

10. Pertimbangan utama pelaksanaan e-Learning adalah untuk memajukan pendidikan. Kepentingan yang lain seperti kepentingan lembaga, kepentingan sosial dan kepentingan politik tidak akan menjamin terwujudnya proses belajar yang lebih baik. (Nichols, 2003)

Kesepuluh hipotesis ini menandaskan bahwa e-Learning merupakan pendidikan yang terjadi hanya melalui Web, tidak memiliki materi cetak bagi kegiatan tatap muka. e-Learning 
dapat dimanfaatkan dalam pendidikan yang mengkombinasikan antara pendidikan tatap muka dan pendidikan jarak jauh yang biasa dinamakan Mixed-mode learning/Resource-based Learning/Blended Learning.

\section{Pembelajaran Blended Learning}

Pembelajaran berbantuan teknologi adalah pembelajaran tatap muka klasikal yang dibantu dengan teknologi media online. Salah satu model pembelajaran berbantuan teknologi yang efektif adalah pembelajaran model Blended Learning.Blended Learning memberikan hasil belajar yang maksimal jika dibanding dengan pembelajaran yang sepenuhnya tatap muka maupun pembelajaran yang sepenuhnya online (Mindflash, ---).

Blended Learning didefinisikan sebagai kombinasi antara pembelajaran tatap muka dan pembelajaran berbasis web (Nichols, 2003; UCF \& AASCU, 2016; Mindflash, ---; Knewton, 2016). Blended Learning menampilkan perubahan besar dalam teknologi pembelajaran yang tidak hanya sekedar menggunakan komputer di dalam pembelajaran. Perubahan yang dihadirkan adalah mengubah pendekatan pembelajaran.Pengalaman belajar siswa dihadirkan sebelum tatap muka (flipped classroom) (Educause, 2005; Mindflash, ---). Setiap saat siswa dapat mengikuti sebagian proses pembelajaran dengan mengakses materi yang dikirim melalui web online. Siswa memiliki kebebasan menentukan waktu dan tempat belajar sesuai dengan kecepatan dan kemampuan belajarnya (NCAT, 2005; Knewton, 2016)

Blended Learning memfasilitasi siswa untuk:

1. memperoleh kegiatan belajar sebagian melalui pembelajaran online dengan keleluasaan waktu, tempat, jalur dan kecepatan belajar

2. memperoleh kegiatan belajar tatap muka di kelas

3. selama proses pembelajaran, setiap siswa saling terhubung untuk memberikan pengalaman belajar yang terintegrasi (Michael B. Horn dan Heather Staker dalam CCI, 2015).

Ketiga kegiatan di atas sesuai dengan tiga komponen utama yang dimiliki oleh Blended Learning, yaitu: 1) kegiatan pembelajaran yang difasilitasi guru terlatih; 2) materi belajar online, termasuk yang telah disiapkan oleh guru kelas; 3) waktu untuk belajar bebas terstruktur dibimbing melalui materi yang dikembangkan selama kegiatan tatap muka (Mindflash, ---).

Ada beberapa model pembelajaran Blended Learning, antara lain: 
1. Face-to-face Driver : Seluruh materi ditampilkan dalam pembelajaran atap muka dengan dukungan suplemen web online (Knewton, 2016).

2. Online Lab Model atau A La Carte Model : Seluruh materi disajikan melalui web online untuk menyertai kegiatan belajar yang lain. Model ini berbeda dengan model fully online karena siswa masih melakukan kegiatan belajar yang lain (Knewton, 2016: CCI, 2015).

3. Rotation : Dalam suatu pembelajaran, para siswa melakukan rotasi jadwal secara tetap antara belajar mandiri secara online dan belajar tatap muka klasikal (Knewton, 2016). Rotasi jadwal bisa pula melibatkan kegiatan kerja kelompok, proyek kerja, bimbingan perorangan, atau tugas tertulis. Model Rotasi memiliki empat sub model, yaitu rotasi pos, rotasi lab, rotasi perorangan dan kelas terbalik (CCI, 2015).

4. Self Blend : Dengan inisiatif sendiri siswa mengikuti pembelajaran online sebagai pelengkap pembelajaran tatap muka

5. Flex : Guru memanfaatkan program online untuk memberi bantuan perseorangan atau sesi bantuan kelompok kecil. Program online memuat sebagian besar materi kurikulum (Knewton, 2016). Materi dalam web online menjadi materi utama kegiatan tatap muka. Pada beberapa model flex, kegiatan tatap muka menjadi pendukung kegiatan online. (CCI, 2015)

6. Online Driver : Seluruh pembelajaran diselesaikan melalui program online dan guru mampu mengontrolnya. Pertemuan tatap muka dijadwalkan bila memang dibutuhkan.

Blended Learning merupakan inovasi yang mengganggu proses pendidikan yang telah mapan selama ini. Inovasi ini menggantikan proses pembelajaran yang mahal, rumit dan tidak mudah diakses semua orang dengan proses pembelajaran yang murah, sederhana dan lebih menyenangkan (Knewton, 2016). Kehadiran inovasi ini memunculkan perubahan yang signifikan dalam proses pembelajaran. Perubahan ini menuntut para pelaku untuk mendesain ulang teknologi, struktur kurikulum, pelatihan pelaku dan dukungan system penilaian. Desain ulang ini dimaksudkan untuk menjamin terwujudnya proses transformasi yang tidak mengganggu, berkelanjutan dan bermakna. Desain ulang ini diperlukan karena kehadiran Blended learning membawa implikasi :

1. pengurangan jumlah pertemuan di kelas, namun tidak menghilangkannya

2. web online tidak menjadi pendukung melainkan menjadi pengganti kegiatan belajar interaktif online yang selama ini menjadi kegiatan unggulan proses pembelajaran 
3. dituntut penilaian yang seksama terhadap pertanyaan mengapa diperlukan tatap muka

4. muncul asumsi bahwa beberapa kegiatan tertentu lebih baik dilakukan secara online, baik perorangan maupun dalam kelompok kecil dibanding dalam bentuk tatap muka langsung.

5. perlu pertimbangan untuk mempertahankan jumlah kegiatan di dalam kelas atau menguranginya

6. perlu pertimbangan untuk membuat perubahan yang signifikan untuk mempertahankan jumlah pertemuan di dalam kelas.

7. diperlukan jadwal kegiatan sepenuhnya terkait dengan penggunaan komputer supaya para siswa dapat berpartisipasi kapanpun dan dimanapun (UCT \& AASCU, 2016).

Dengan persiapan yang baik, Blended Learningakan memberikan hasil yang optimal. Pembelajaran Blended Learning memungkinkan untuk menggunakan waktu tatap muka bagi kegiatan yang paling bermanfaat. Pembelajaran tradisionil cenderung menggunakan waktu tatap muka untuk menyampaikan materi melalui ceramah. Dalam Blended Learning, materi ceramah telah direkam dan disampaikan sebelum tatap muka sehingga siswa dapat menyaksikan materi ceramah di waktu luang mereka sebelum kegiatan tatap muka.

Guru dituntut secermat mungkin memberikan alasan mengapa dan seberapa sering melakukan pembelajaran tatap muka (NCAT, 2005). Perlu pertimbangan yang matang untuk melakukan pembelajaran tatap muka. Pertimbangan ini didasarkan bukti bahwa beberapa pembelajaran tertentu lebih efisien dan efektif dilakukan secara online. Waktu tatap muka lebih digunakan untuk latihan yang terstruktur yang menekankan penerapan materi dalam menyelesaikan masalah atau dalam penyelesaian tugas (Mindflash, ---). Waktu tatap muka diprioritaskan untuk pencapaian hasil belajar pada tiga ranah kognitif awal, yaitu pengetahuan, pemahaman dan penerapan. Guru diharapkan melakukan perubahan yang signifikan dalam pembelajaran tatap muka. 


\section{KESIMPULAN}

Blended Learning merupakan salah satu bentuk pendidikan yang memanfaatkan $e$ Learning dalam proses pelaksanaannya. Kombinasi antara kegiatan pembelajaran tatap muka dan pembelajaran online memungkinkan siswa memperoleh tambahan waktu mengikuti proses pembelajaran dan kesempatan untuk memperluas cakrawala materi melalui sumber lain. Partisipasi yang biasa diperoleh siswa dalam pembelajaran tatap muka dibatasi waktunya setelah paparan materi.

Paparan materi dalam Blended Learning disajikan di luar alokasi waktu pembelajaran, bahkan bukan saja paparan materi, latihan soal dan konsultasi kesulitan memahami materi dan soal bisa dilakukan di luar alokasi waktu pelajaran. Melalui interaksi online, para siswa bisa saling berkonsultasi dengan sesama teman atau dengan guru. Partisipasi siswa tidak hanya selama alokasi waktu pelajaran di kelas, mereka bisa memanfaatkan seluruh waktu di rumah untuk menambah waktu partisipasi dalam pembelajaran.

Saat pembelajaran tatap muka di kelas, siswa bisa meningkatkan kualitas partisipasinya melalui program yang telah disusun guru. Dengan asumsi bahwa para siswa telah menguasai dasar-dasar materi yang seharusnya disajikan di dalam kelas, guru biasanya memfokuskan pembelajaran di kelas dengan kegiatan yang masuk dalam tiga tingkatan taksonomi yang tinggi, yaitu sintesa, analisis dan evaluasi. Partisipasi berupa kegiatan mengetahui, memahami dan menerapkan konsep matematika dilakukan para siswa di rumah melalui pembelajaran online. Di kelas, mereka bisa fokus berlatih memecahkan masalah dalam ranah kognitif yang tinggi yang meliputi analisis, sistesis dan evaluasi. Penambahan waktu dan peningkatan kualitas partisipasi siswa dalam pembelajaran diharapkan dapat meningkatkan kompetensi siswa dalam materi yang disajikan guru selama pembelajaran. 


\section{Daftar Pustaka}

CCI. 2015. Blended Learning Definitions. Clayton Christensen Institute for Disruptive Innovation. Diunduh dari http://www.christenseninstitute.org/blended-learningdefinitions-and-models/

Civil, Marta \& Planas, Nuria. 2004. Participation in The Mathematics Classroom: Does every student have a voice?.For The Learning of Mathematics.FLM Publishing Association, Kingston, Ontario, Canada. Diunduh dari http://math.arizona.edu/ civil/Civil-Planas\%2024(1)\%20FLM\%20.pdf

Clarke, David. 2004. Patterns of Participation in the Mathematics Classroom. Proseedings of he 28 th Conference of the international Group for the Psychology of Mathematics Education. Vol.2 pp 231-238. Diunduh dari https://www.emis.de/proceedings/ PME28/RR/RR121_Clarke.pdf

De Gaer, Eva Van; Pustjens, Heidi; Damme, Jan Van; dan De Munter, Agnes. 2008. Mathematics Participation and mathematics Achievement Across Secondary School: The Role of Gender. Springer Science + Business Media.Diterbitkan online: 10 Mei 2008. Diunduh dari link.springer.com/article/10.1007/s11199-008-9455-x

Educause. 2012. Things you should know about: Flipped Classrooms. Educause: Learning Initiative. Diunduh dari https://net.educause.edu/ir/library/pdf/eli7081.pdf

Gresalfi, Melissa; Martin, Taylor; Hand, Victoria and Greeno, James. 2009. Contructing competence: an analysis of student participation in the activity systems of mathematics classrooms. Educ Stud Math.(2009) 70:49-70.Published online: 3 September 2008. Springer Science + Business media B.V. Diunduh dari http://link.springer.com/article/10.1007/s10649-008-9141-5\#page-2

Knewton. 2011. Blended Learning: A Disruptive Innovation. Innosight Institute and Charter School Growth Fund. Diunduh dari https://www.knewton.com/infographics/blendedlearning/

Mindflash. ---. What is Blended learning? Easy Online Training. Mindflash Technologies Inc. Diunduh dari https://www.mindflash.com/e-Learning/what-is-blended-learning/

NCAT. 2005. The Replacement Model.The National Center for Academic Transformation, Saratoga Spring, New York. Diunduh dari http://www.thencat.org/index.html

Nichols, Mark. 2003. A Theory for e-Learning. Educational Technology \& Society. 6(20, 1-10. (ISSN 1436-4522).Diunduh dari www.ifets.info/journals/6 2/1.html.

Nurmawati; Ismartoyo dan Prayitno, Edi. 2015. Pengembangan E-Modul dengan Model Guided Note Taking (GNT) pada Mata Kuliah Pendidikan Matematika II Program S1 PGSD BI di Pokjar Kota Semarang.Hasil Penelitian Fundamental Universitas Terbuka. Tidak Dipublikasikan.

OECD, 2013. Mathematics Self-Beliefs and Participation in Mathematics Related Activities. Ready to learn: Sudents' Engagement, Drive and self-Beliefs. Vol. III. Diunduh dari www.oecd.org/pisa/keyfindings/PISA2012-Vol3-Chap4.pdf

Pappas, Christopher. 2014. The Benefits of Big Data and its Impact in The Future of e-Learning industry. e-Learning industry. Diunduh dari https://e-Learningindustry.com/big-datain-e-Learning-future-of-e-Learning-industry

The Reflective Educator, 2015.Participation in Math Class.Diunduh dari http://davidwees .com/content/participation-in-math-class/

UCF \& AASCU. 2016. What is Blended Learning? Blended Learning Toolkit.University of Florida and American Association of State Colleges and Universities. Diunduh dari https://blended.online.ucf.edu/about/what-is-blended-learning/ 
USciences. 2016. Student Participation/Active learning. University of the Sciences in Philadelphia. Diunduh dari http://www.usciences.edu/teaching/tips/spal.shtml \#promoting 